\title{
PERUBAHAN SOSIAL BUDAYA MASYARAKAT KOREA SELATAN AKIBAT PANDEMI COVID-19
}

\author{
Margareth Theresia \\ Kyung Hee University \\ theresia.margareth@khu.ac.kr
}

\begin{abstract}
Pandemi Covid-19 yang muncul di akhir tahun 2019 mengubah wajah Korea Selatan. Masyarakat Korea Selatan yang sangat patuh dengan pemimpinnya membuat masyarakat Korea mengikuti setiap anjuran dan rekomendasi pemerintah, namun membuat beberapa kebiasaan seperti kebiasaan hwesik menghilang untuk sementara. Melalui berita-berita dan pengumuman kebijakan pembatasan sosial yang dikeluarkan oleh pemerintah Korea Selatan pada bulan Maret hingga April 2020, penulis melihat hal-hal yang berubah di dalam masyarakat Korea Selatan. Korea Selatan sudah mulai berangsur normal dengan pengurangan jumlah pasien positif setiap harinya, tetapi masyarakat yang sudah mulai terbiasa untuk tinggal di rumah saja dan berhubungan melalui internet, akan merasa asing saat mulai kembali beraktivitas di luar rumah dan kantor.
\end{abstract}

Keywords: virus corona, pandemic covid-19, kebiasaan masyarakat Korea, budaya masyarakat Korea, hwesik

Received 29 April 2020 Accepted 6 February 2021

\section{INTRODUCTION}

Pada akhir tahun 2019, dunia digegerkan oleh sebuah virus baru yang menyerang pernapasan dan membuat penderitanya terkena pneumonia. Virus baru yang belum diketahui bentuk atau sifatnya itu lalu disebut Virus Wuhan. Virus ini disebut Virus Wuhan karena pasien-pasien awal berasal dari Kota Wuhan. Pasien-pasien yang awalnya hanya berada di Kota Wuhan tersebut menularkan virus tersebut ke orang-orang di sekelilingnya sehingga penyebaran ke negaranegara sekitarnya dimulai pada Januari 2020 dan hingga April 2020, virus ini sudah menyebar ke seluruh dunia sehingga WHO menyatakan penyebaran penyakit baru ini sebagai Pandemi Covid-19 [1].

Pandemi Covid-19 atau yang sebelumnya disebut sebagai Virus Wuhan masuk ke Korea Selatan mulai Januari 2020 [2]. Kasus pertama di Korea Selatan tercatat pada 19 Januari 2020 dan dilaporkan ke publik pada 20 Januari 2020. Pasien positif pertama adalah seorang turis wanita berusia 35 tahun yang berasal dari Kota Wuhan, Tiongkok. Saat gejala terjangkit virus korona terdeteksi di Bandara Incheon, turis tersebut langsung dibawa ke rumah sakit di Kota Incheon untuk diisolasi dan dirawat. Kasus ini membuat Korea Selatan menaikkan level kewaspadaan dari warna biru (normal) menjadi warna kuning (hati-hati). Pusat Kontrol dan Pencegahan Penyakit Korea Selatan (Korea Centers for Disease Control and Prevention, KCDC) pun mulai mengeluarkan berbagai peringatan dan pedoman bagi masyarakat untuk berhati-hati dengan virus baru ini. Pedoman awal tersebut antara lain adalah mencuci tangan selama 30 detik dan menutup mulut dengan lengan baju saat batuk. Masyarakat yang mengunjungi Wuhan dan menunjukkan gejala harus menghubungi KCDC.

Masyarakat Korea Selatan sudah mulai berhati-hati dan sebagian sudah memakai masker semenjak kemunculan pasien positif pertama, tetapi pasien nomor 31 mengubah masyarakat 
Korea Selatan menjadi sangat waspada terhadap penyebaran virus baru ini. Pasien nomor 31 merupakan seoarang wanita berusia 61 tahun yang tinggal di Kota Daegu yang berjarak $237 \mathrm{~km}$ dari Kota Seoul. Pasien tersebut merupakan korban dari kecelakaan lalu lintas pada tanggal 6 Februari dan dirawat di rumah sakit di kota Daegu hingga 17 Februari 2020. Selama dirawat di rumah sakit, pasien tersebut sempat makan di luar dengan teman-temannya serta mengunjungi gereja selama beberapa kali. Pasien ini sempat dites untuk virus corona dan dinyatakan positif per tanggal 18 Februari 2020. Ia sempat mengikuti ibadah besar di gerejanya dan menulari umat lain sehingga terjadi outbreak atau penyebaran wabah dengan cepat di Kota Daegu. Korea Selatan pun akhirnya menaikkan level kewaspadaan menjadi merah (awas) per tanggal 23 Februari 2020 [3].

\section{RESEARCH METHOD(S)}

Penelitian dilakukan dengan menggunakan studi literatur melalui buku Hangukmunhwaeui Ihae(한국문화의 이해: Essentials of Korean Culture) serta berita dan pengumuman pemerintah terkait dengan pandemic Covid-19 di Korea Selatan. Berita yang dipakai adalah berita yang dipublikasikan oleh 5 media terbesar di Korea Selatan berdasarkan data yang dihimpun oleh Korean Statistical Information Service, yaitu Yonhap News, Joongang Ilbo, Kookmin Ilbo, News1, dan Chosun Ilbo [4]. Pengumuman pemerintah yang dipakai adalah pengumuman dari KCDC yang dipublikasikan di situs terpadu Covid-19 Korea Selatan (http://ncov.mohw.go.kr/). Data yang didapat digunakan sebagai acuan penelitian.

\section{LITERATURE REVIEW}

Korea Selatan adalah negara yang terletak di Asia Timur dan memiliki sejarah yang panjang. Pola pikir dan kebiasaan masyarakat Korea Selatan dipengaruhi oleh Syamanisme, Taosime, agama Buddha, dan juga Konfusianisme. Oleh karena itu, untuk memahami kebudayaan dan kebiasaan masyarakat Korea Selatan, diperlukan pemahaman yang dalam mengenai Syamanisme, Taoisme, agama Buddha, dan Konfusianisme di Korea Selatan [5]. Syamanisme di Semenanjung Korea memiliki sejarah yang sangat panjang hingga ribuan tahun dan saat ini syaman atau dukun masih bisa dengan mudah ditemui di Korea Selatan. Kesenian tradisional Korea pun masih banyak mendapatkan pengaruh dari syamanisme. Tidak diketahui kapan Taoisme masuk ke Semenanjung Korea, tetapi Taoisme dipastikan masuk dari Tiongkok sebelum masehi. Sistem kalender tradisional Korea dan berbagai cara hidup masyarakat Korea dipengaruhi oleh Taoisme. Agama Buddha masuk ke Korea Selatan sekitar abad ke-4 dan mempengaruhi pola pikir masyarakat Korea.

Konfusianisme masuk ke Semenanjung Korea pada abad ke-3 SM dan sangat mempengaruhi kehidupan masyarakat Korea, bahkan hingga saat ini. Hierarki dalam masyarakat Korea sangat kuat karena 3 prinsip dasar dan 5 prinsip moral yang disebut sebagai samgang oryun(삼강오륜). 3 prinsip dasar tersebut adalah bawahan yang loyal kepada pemimpin/raja, anak yang berbakti kepada orang tua, dan istri yang setia kepada suami. Sedangkan 5 prinsip moral tersebut adalah kedekatan antara anak dan ayah, kesetiaan di antara raja/pemimpin dan bawahannya, sekat di antara suami dan istri, perbedaan status antara yang lebih tua dan yang lebih muda, serta kepercayaan di antara teman. Hierarki karena prinsip ini sangat terlihat dalam kehidupan sehari-hari, baik di rumah, sekolah, maupun di tempat kerja.

Campuran dari berbagai pemahaman ini dapat terlihat dalam kehidupan. masyarakat Korea Selatan pada umumnya, terutama Konfusianisme. Menurut 3 prinsip dasar dan 5 prinsip moral tersebut, masyarakat Korea Selatan dibuat untuk patuh terhadap peraturan yang dikeluarkan oleh pemerintahnya. Walaupun Korea Selatan memegang merupakan negara demokrasi, tetapi ideologi Konfusianisme yang sudah tertanam berabad-abad di dalam diri masyarakat Korea Selatan, tidak bisa diabaikan begitu saja. Walaupun tidak suka ataupun mengkritik kebijakan pemerintah, masyarakat tetap patuh mengikuti anjuran pemerintah karena bawahan yang harus loyal kepada pemimpinnya, dalam hal ini adalah masyarakat yang harus loyal kepada pemerintahnya. Dalam kasus pandemik Covid-19 ini dapat terlihat betapa prinsip ini 
berpengaruh dalam kehidupan masyarakatnya. Berkat masyarakat yang patuh ini, pemerintah bisa dengan mudah mengontrol penyebaran Covid-19 di masyarakat dan kurva penyebaran virus bisa turun dengan cepat.

\section{FINDINGS AND DISCUSSION}

Semenjak virus corona baru ini masuk ke Korea Selatan per Januari 2020, pemerintah Korea Selatan memberikan informasi terbaru mengenai perkembangan virus ini melalui situs yang dibuat oleh KCDC. Masyarakat bisa dengan bebas melihat respons pemerintah dan penyebaran virus ini di situs tersebut. Informasi dalam situs tersebut tersedia dalam bahasa Korea dan bahasa Inggris. Selain dari data yang dipaparkan di dalam situs pemerintah, pemerintah juga melakukan briefing secara live sebanyak 2 kali sehari pada pagi hari dan sore hari untuk memberitahu ke publik mengenai keadaan penyebaran virus yang terjadi dan juga usaha pemerintah dalam menanganinya. Pemerintah juga menyampaikan kebijakan-kebijakan baru terkait Covid-19 melalui briefing tersebut.

Titik balik jumlah penambahan pasien positif di Korea Selatan dimulai dari pasien ke-31. Sebelum pasien ke-31 muncul, masyarakat sudah berhati-hati namun menjadi lebih waspada setelah pasien ke-31 dilaporkan ke publik. Jumlah pasien positif di Korea Selatan dari pasien ke-31 hingga 28 April dapat dilihat di grafik berikut ini. Puncak kurva pandemik ini terjadi pada 10 Maret 2020 namun perlahan-lahan menurun hingga laporan per tanggal 28 April 2020.

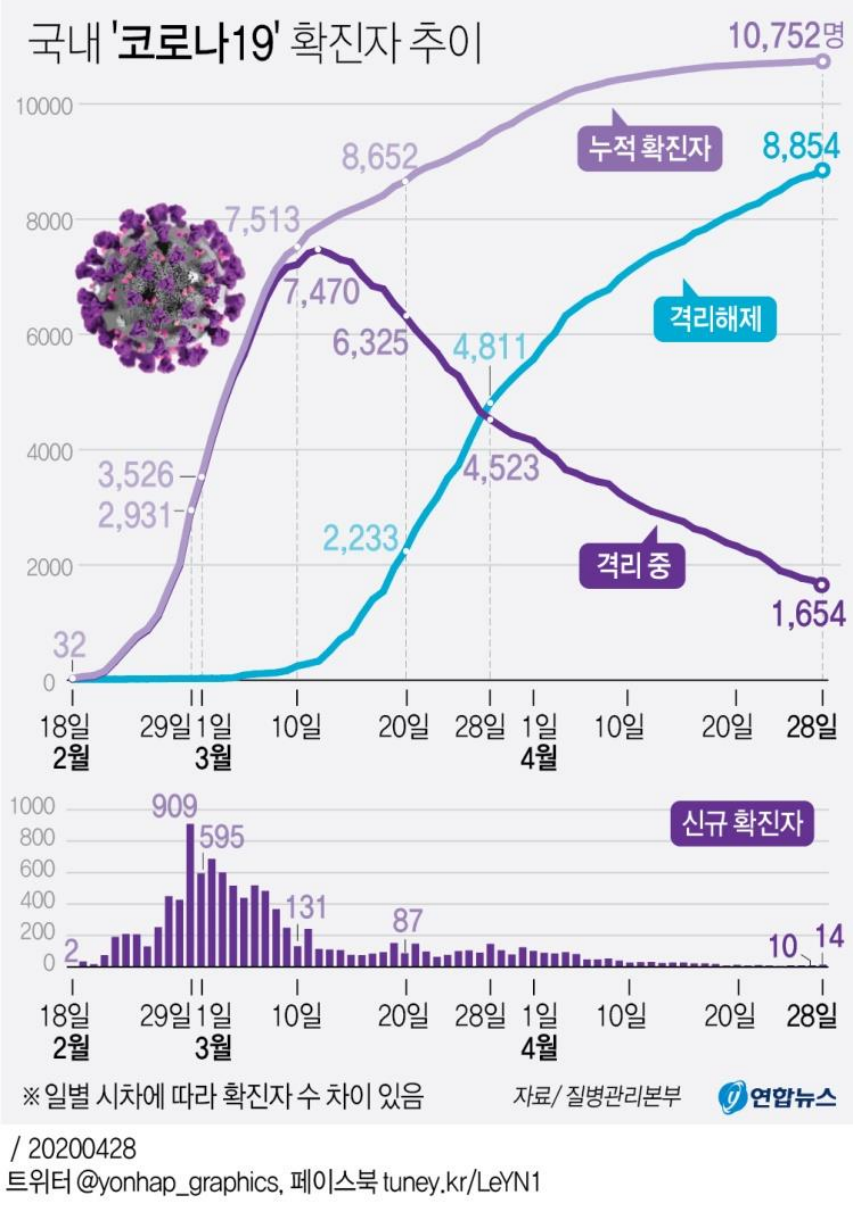

Gambar 1. Grafik Pasien Positif di Korea Selatan [6]

Pasien positif pertama di Korea Selatan dilaporkan pada 20 Januari 2020 dan mencapai angka 32 orang pada 18 Februari 2020. Jumlah penambahan pasien positif tertinggi tercatat pada 29 Februari 2020 dengan 909 orang dan jumlah pasien positif per 28 April 2020 adalah 10.752 orang dengan pasien yang sembuh mencapai 8.854 orang. Jumlah penambahan pasien positif yang sangat tinggi ini sangat berkaitan dengan penyebaran virus di gereja pasien ke-31 yang mengadakan ibadah besar pada tanggal 16 Februari 2020. Umat dari gereja yang bernama Shincheonji ini datang dari seluruh penjuru Korea Selatan sehingga umat-umat yang tertular 
pada ibadah di tanggal 16 Februari 2020 ini membawa virus ke seluruh penjuru Korea Selatan. Pusat penyebaran virus corona baru ini memang di Daegu dan sekitarnya, tetapi umat-umat gereja tersebut turut membawa penyebaran virus ke seluruh penjuru Korea Selatan [7].

Penambahan jumlah pasien positif yang cukup signifikan per harinya membuat masyarakat panik tetapi tidak disertai dengan panic buying. Panic buying tidak terjadi di Korea Selatan sehingga mampu menggegerkan dunia karena di negara lain banyak terjadi kasus panic buying di saat kurva pasien positif mulai meningkat. Hal ini terjadi karena Korea Selatan merasa aman kaena pemerintah menenangkan masyarakat mengenai suplai barang-barang pokok yang akan tetap aman walaupun jumlah pasien positif tetap bertambah. Namun jumlah pembelanjaan online dan pengiriman barang tercatat meningkat pesat setelah pasien ke-31 dilaporkan ke publik. Jumlah peningkatan tersebut tercatat hingga 200\% per tanggal 23-29 Februari 2020 berdasarkan laporan CJ Logistic [8].

Hingga minggu ke-4 April 2020, setiap hari masih saja terdapat penambahan pasien positif sehingga masyarakat Korea Selatan masih memakai masker saat keluar rumah. Pembelian masker KF94 dan sejenisnya dibatasi pemerintah per 9 Maret 2020 karena penimbunan masker yang membuat masker langka di pasaran. Pemerintah membatasi masyarakat untuk bisa membeli hanya 2 masker per minggu saja [9]. Jumlah ini dinaikan menjadi 3 masker per minggu pada 27 April 2020 [10]. Masyarakat Korea Selatan sudah terbiasa memakai masker sebelum adanya Covid-19 karena udara yang kurang bagus. Korea sering dilanda badai debu dari Tiongkok dan juga polusi udara dari pabrik-pabrik yang ada di Korea Selatan sehingga dengan adanya pandemic Covid-19 ini, masyarakat Korea Selatan tidak merasa kaget untuk menggunakan masker. Hampir setiap orang menggunakan masker saat keluar rumah sesuai dengan ajuran pemerintah.

Korea tidak pernah menutup perbatasan atau me-lockdown wilayahnya, tetapi pemerintah 'hanya' melakukan pembatasan sosial sejak pasien positif nomor 31 dilaporkan ke publik. KCDC sendiri mengumumkan detail kampanye pembatasan sosial per 23 Maret 2020. Publik diminta untuk tetap tinggal di rumah sebisa mungkin, kecuali untuk pergi membeli bahan pokok, bahan kesehatan, atau pergi kerja. Kemudian pemerintah meminta masyarakat untuk membatalkan semua acara di luar rumah dan rencana wisata. Peraturan ini dibuat untuk mengurangi kegiatan masyarakat di luar ruangan dan untuk mencegah penyebaran virus yang lebih massif. Jumlah masyarakat yang keluar rumah di masa ini menurun drastis dibandingan sebelum kampanye ini dimulai.

Masyarakat Korea Selatan adalah masyarakat yang bersifat sangat sosial dan sangat suka berkumpul untuk makan bersama. Budaya makan bersama tersebut disebut hwesik(회식). Hwesik paling banyak dilakukan di lingkungan kantor, tetapi dilakukan juga pada kehidupan bersosial masyarakat pada umumnya. Biasanya hwesik diadakan mulai dari ronde 1 hingga ronde 5 tergantung pada komunitas yang melakukannya. Jenis $h w e s i k$ bermacam-macam tetapi secara umum adalah makan bersama, minum alkohol bersama, dan diakhiri dengan bernyanyi bersama di karaoke. Oleh karena itu, umum sekali melihat orang-orang Korea Selatan berkumpul bersama dan mengobrol satu sama lain saat hwesik [12]. Akan tetapi, budaya ini menjadi pelan-pelan menghilang karena aturan pembatasan sosial tersebut. Masyarakat Korea Selatan sudah terbiasa untuk melakukan kontak sosial melalui hweik, tetapi karena adanya pembatasan sosial ini, mereka terpaksa untuk makan sendiri-sendiri dan mengurangi kontak dengan orang lain. Masyarakat yang terbiasa untuk berkumpul bersama ini akhirnya terpaksa untuk menjadi individualis.

Beberapa perusahaan yang memiliki kantin perusahaan juga memasang kaca untuk memisahkan satu karyawan dengan karyawan lainnya saat makan. Karyawan kantor yang biasanya bisa mengobrol satu sama lain saat istirahat makan siang terpaksa harus makan sendiri-sendiri dan tidak bisa mengobrol satu sama lain. Karyawan juga terpaksa untuk mengantri dengan jarak 1-2 meter satu sama lain [13]. 


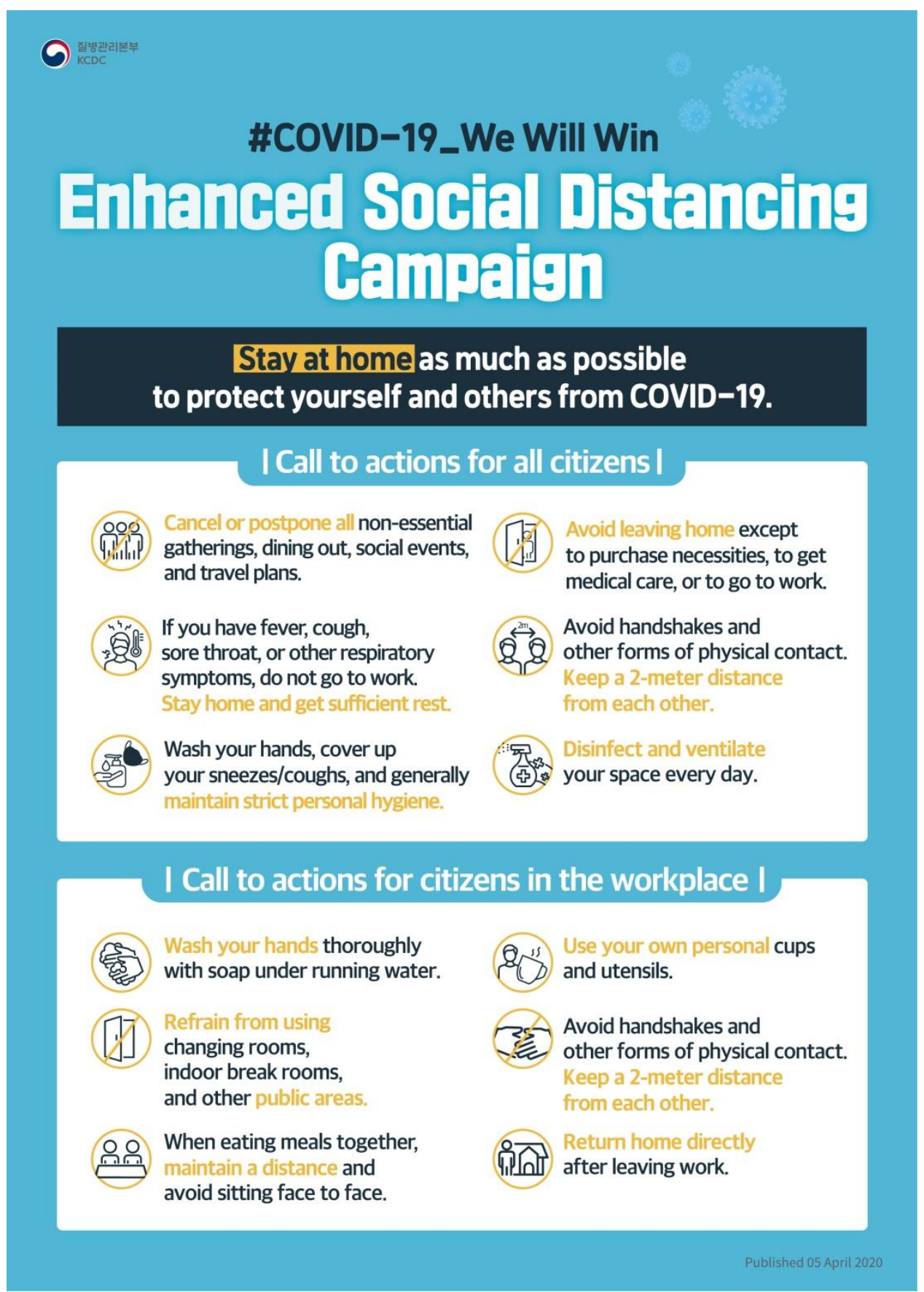

Gambar 2. Kampanye Pembatasan Sosial oleh KCDC [11]

Peraturan pembatasan sosial yang dikeluarkan oleh KCDC per 23 Maret tersebut juga memuat kewajiban untuk menutup fasilitas keagamaan, fasilitas olahraga dalam ruangan, dan juga fasilitas hiburan. Selain itu, KCDC meminta kepada pemerintah lokal untuk menutup warnet, karaoke, dan institut pendidikan. Peraturan ini muncul karena penyebaran virus yang cukup massif di beberapa gereja, warnet, dan karaoke. Peraturan ini membuat masyarakat Korea Selatan semakin tidak bisa behubungan langsung dengan orang lain. Tidak hanya fasilitas-fasilitas tersebut, museum-museum nasional, perpustakaan-perpustakaan nasional, dan galer-galeri nasional juga ditutup [14]. Oleh karena itu, masyarakat Korea Selatan tidak memiliki pilihan lain selain tinggal di rumah. Hanya ada pengecualian bagi para karyawan yang harus pergi ke kantor. Peraturan ini awalnya hanya dilaksanakan selama 2 minggu, tetapi terus diperpanjang hingga 19 April 2020 [15].

Jumlah penambahan pasien positif yang semakin menurun setiap harinya membuat pemerintah mengurangi intensitas pembatasan sosial pada masyarakat. Rekomendasi 
pembatasan sosial diperpanjang hingga 5 Mei dengan berbagai ketentuan. Masyarakat sudah bisa menggunakan fasilitas agama, fasilitas olahraga, dan juga institusi pendidikan dengan tetap menggunakan masker dan juga menggunakan hand sanitizer sebelum masuk ke dalam ruangan. Pemerintah juga meminta setiap fasilitas untuk memiliki daftar nama orang-orang yang datang setiap harinya [16]. Pemerintah menambah periode pembatasan sosial sebanyak 16 hari, bukan 14 hari karena hari libur nasional pada 30 April 2020 (Waisak di Korea), 1 Mei 2020 (Hari Buruh), dan 5 Mei 2020 (Hari Anak di Korea Selatan). 3-4 orang dari 10 orang di Korea Selatan memiliki rencana untuk berwisata pada hari libur panjang kali ini dan pemerintah tidak bisa mencegah masyarakat untuk bepergian karena kuatir dengan kondisi mental masyarakat yang sudah terlalu lama direkomendasikan untuk tinggal di rumah, namun pemerintah memberikan pedoman untuk bisa berwisata dengan aman di masa libur panjang ini [17].

Pengurangan intensitas pembatasan sosial membuat KCDC mengeluarkan pedoman pembatasan sosial dalam kehidupan sehari-hari pada 22 April 2020 [17]. Pedoman kali ini adalah pedoman yang cukup mirip dengan pedoman-pedoman yang sudah dikeluarkan sebelumnya. Pedoman tersebut berisi mengenai 5 langkah dasar dan beberapa detail mengenai hal-hal yang harus dilakukan pada ruangan tertutup.

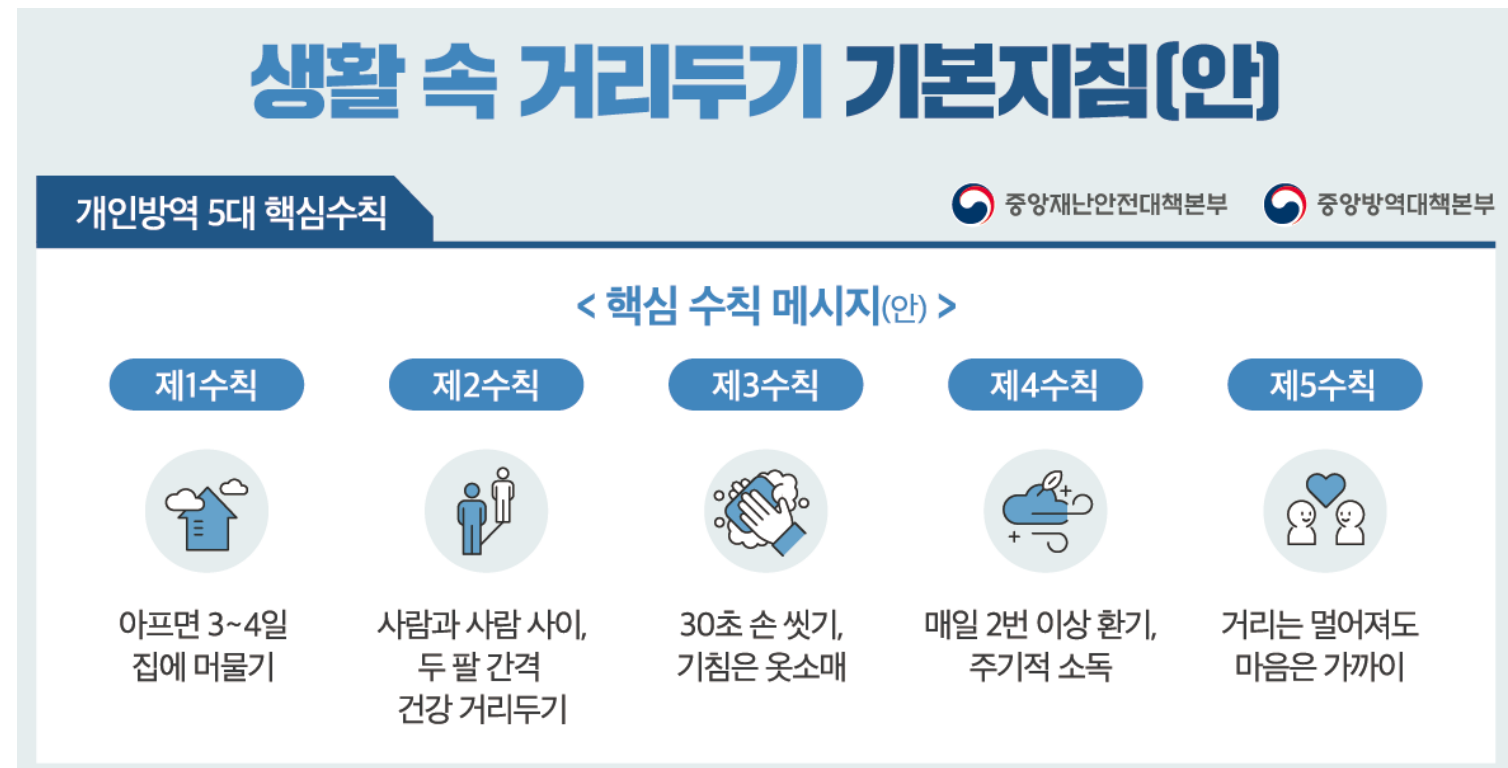

Gambar 3. 5 Pedoman Dasar Pembatasan Sosial dalam Kehidupan Sehari-hari

5 langkah dasar tersebut adalah tinggal di rumah selama 3-4 hari jika sakit, menjaga jarak sekitar 1-2 meter dengan orang lain, menjaga kebersihan, melakukan pertukaran udara, dan juga tetap berhubungan dengan sesama walaupun menjaga jarak. Pemerintah juga mewajibkan masyarakat untuk tetap memakai masker apabila keluar rumah. Selain itu, pemerintah juga menyarankan masyarakat untuk melakukan salam dengan menundukkan kepala, bukan dengan bersalaman tangan atau berpelukan. Apabila batuk, masyarakat diwajibkan untuk menutup mulut dengan lengan baju, bukan dengan tangan. Ruangan tertutup harus dibuka setidaknya 2 kali sehari agar udara di dalam ruangan menjadi lebih segar dan ruangan harus disterilkan setiap hari. Pemerintah juga menyarankan masyarakat untuk berhubungan satu sama lain melalui aplikasi pesan dan mengurangi pertemuan tatap muka.

Masyarakat Korea Selatan sudah mulai beraktivitas secara normal karena jumlah penambahan pasien positif yang semakin berkurang setiap harinya, tetapi untuk kembali beraktivitas normal seperti sebelum virus corona baru ini muncul sepertinya akan cukup sulit. Aktivitas tatap muka akan semakin berkurang ke depannya dan akan digantikan dengan aktivitas online melalui aplikasi pesan. Kemudian kegiatan berkumpul juga akan berkurang. Kegiatan individual akan semakin bertambah sehingga mungkin saja kebudayaan kumpulkumpul bersama tidak akan sebanyak dulu sebelum munculnya virus corona. 


\section{CONCLUSION}

Pandemi Covid-19 mengubah wajah Korea Selatan, terutama karena anjuran pembatasan sosial oleh pemerintah Korea Selatan. Pasien ke-31 mengubah kehati-hatian masyarakat Korea Selatan menjadi kewaspadaan, terutama setelah pembatasan sosial dianjurkan oleh pemerintah selama satu setengah bulan. Masyarakat yang terbiasa untuk berkumpul di luar, sekarang menjadi terkungkung di rumah dan tempat kerja saja. Kegiatan ajar mengajar serta hubungan personal hanya bisa dilaksanakan melalui aplikasi pesan sehingga kegiatan tatap muka semakin berkurang. Korea Selatan sudah mulai berangsur normal dengan pengurangan jumlah pasien positif setiap harinya, tetapi masyarakat yang sudah mulai terbiasa untuk tinggal di rumah saja dan berhubungan melalui internet, akan merasa asing saat mulai kembali beraktivitas di luar rumah dan kantor.

\section{REFERENCES}

[1] https://www.who.int/csr/don/12-january-2020-novel-coronavirus-china/en/, diakses 29 April 2020.

[2] https://www.yna.co.kr/view/AKR20200120087153017, diakses 25 April 2020.

[3] https://www.yna.co.kr/view/AKR20200417061351052, diakses 25 April 2020.

[4] http://www.bigtanews.co.kr/news/articleView.html?idxno=5214, diakses 25 April 2020.

[5] 손호민, 전상이, etc. 한국문화의 이해(Essentials of Korean Culture), Korea University Press, Seoul, 2013.

[6] https://www.yna.co.kr/view/GYH20200428000600044?section=graphic/index, diakses 28 April 2020.

[7] https://www.news1.kr/articles/?3849515, diakses 29 April 2020.

[8] https://www.yna.co.kr/view/AKR20200308052800002, diakses 28 April 2020.

[9] https://www.yna.co.kr/view/AKR20200426056600017, diakses 28 April 2020.

[10] http://ncov.mohw.go.kr/en/infoBoardView.do?brdId=14\&brdGubun=141\&dataGubun= \&ncvContSeq=1551\&contSeq=1551\&board_id=\&gubun=, diakses 29 April 2020.

[11] 오주현, 직장인들의 탈출구, 회식 - '사화만사성'을 위한 즐거운 회식을, 위하여, CAD \& Graphics. 209 (2011) 86-87.

[12] https://www.yonhapnewstv.co.kr/news/MYH20200307001600641, diakses 29 April 2020.

[13] https://news.joins.com/article/23713792, diakses 29 April 2020.

[14] http://m.kmib.co.kr/view.asp?arcid=0014442880, diakses 29 April 2020.

[15] https://www.yna.co.kr/view/AKR20200419060100017, diakses 29 April 2020.

[16] https://www.yna.co.kr/view/AKR20200429096100003, diakses 29 April 2020.

[17] http://ncov.mohw.go.kr/guidelineView.do?brdId=6\&brdGubun=61\&dataGubun=\&ncvC ontSeq=1996\&contSeq=1996\&board id=\&gubun=, diakses 25 April 2020. 